\title{
Culture et mobilisation politiques en période de révolution. L'exemple du mouvement pétitionnaire d'Esslingen de 1848-1849
}

Carola Lipp

\section{OpenEdition}

\section{Journals}

Electronic version

URL: http://journals.openedition.org/rh19/120

DOI: $10.4000 /$ rh19.120

ISSN: $1777-5329$

Publisher

La Société de 1848

Printed version

Date of publication: 1 December 1997

ISSN: 1265-1354

\section{Electronic reference}

Carola Lipp, «Culture et mobilisation politiques en période de révolution. L'exemple du mouvement pétitionnaire d'Esslingen de 1848-1849 », Revue d'histoire du XIXe siècle [Online], 15 | 1997, Online since 04 September 2008, connection on 23 April 2019. URL : http://journals.openedition.org/rh19/120 ; DOI : 10.4000/rh19.120

This text was automatically generated on 23 April 2019

Tous droits réservés 
Culture et mobilisation politiques en période de révolution. L'exemple du mouvement pétitionnaire d'Esslingen de 1848-1849

\author{
Carola Lipp
}

\title{
ABSTRACTS
}

No abstract available by now

Pas de résumé disponible actuellement

INDEX

Mots-clés: 1848, Esslingen 